\title{
PENGARUH KOTORAN AYAM DAN MIKORIZA Glomus aggregatum TERHADAP PERTUMBUHAN KEDELAI (Glycine max) PADA TANAH GAMBUT
}

\author{
Muhamad Iqbal $^{1 *}$, Riza Linda ${ }^{1}$, Mukarlina ${ }^{1}$ \\ ${ }^{1}$ Program Studi Biologi, Fakultas Matematika \& Ilmu Pengetahuan Alam, Universitas Tanjungpura \\ Jl. Prof. Dr. H. Hadari Nawawi, Pontianak \\ *email : iqbalkalbarptk@gmail.com
}

\begin{abstract}
Peat soil in West Kalimantan has been contained low of nutrient level so it affects the growth of soybeans. One effort to increase the availability of nutrients in peat soils is by using mycorrhiza and chicken manure fertilizer. This research aims to determine the growth of soybeans by administering chicken manure and mycorrhiza on peat soils. The research was conducted from January to April 2019. The research design used was a Completely Randomized Design Factorial consisting of 2 factors with 4 replications. The first factor is mycorrhiza fungi: M1 (0 gr/polybag), M2 (5 gr/polybag), M3 (10 gr/polybag), M4 (15 gr/polybag) and the second factor is chicken manure fertilizer: P1 (0 tons/ha), P2 (5 tons/ha), P3 (10 tons/ha), P4 (15 tons/ha). The results showed that the single chicken manure application significantly affected all observed parameters with 15 tons/ha chicken manure fertilizer. Mycorrhiza fungi just a significantly effect on fresh weight and dry weight. Also, the combination of mycorrhiza fungi and chicken manure fertilizer just a significantly affected wet weight and dry weight with combination $5 \mathrm{~g}$ mycorrhiza and 5 tons/ha of chicken manure fertilizer.
\end{abstract}

Keywords: Chicken manure, growth, mycorrhiza, soybean (Glycine max L.)

\section{PENDAHULUAN}

Kedelai merupakan komoditas pangan dengan kandungan protein nabati tinggi dan telah digunakan sebagai bahan baku produk olahan seperti susu kedelai, tempe, tahu, dan kecap. Kedelai juga berperan penting sebagai sumber protein, karbohidrat dan minyak nabati, $100 \mathrm{~g}$ biji kedelai mengandung 18\% lemak, 35\% karbohidrat, $8 \%$ air, 330 kalori, $35 \%$ protein dan 5,25\% mineral (Suprapto, 1985). Kebutuhan akan komoditas pangan kedelai, membuat upaya budidaya kedelai penting dilakukan untuk memperbaiki pertumbuhan kedelai di Kalimantan Barat yang masih terbatas dan dapat disebabkan oleh kondisi lahan pertanian dengan kandungan unsur hara yang rendah.

Varietas kedelai yang digunakan untuk budidaya kedelai di Kalimantan Barat, antara lain Anjasmoro, Agromulya, Burangrang, Wilis, dan Sinabung. Penelitian yang dilakukan Mayadewi (2007), penggunaan varietas kedelai oleh petani di Kubu Raya, Kalimantan Barat menunjukkan penggunaan kedelai varietas Agromulya, Grobogan serta Anjasmoro merupakan jenis varietas kedelai yang memiliki produksi tinggi $(2,01$ ton/ha) serta banyak digunakan oleh petani di Kalimantan Barat secara turun temurun dari produksi sebelumnya. Penggunaan varietas Sinabung belum banyak digunakan petani, sehingga perlu dilakukan upaya budidaya pada varietas tersebut.

Pupuk organik yang berasal dari kotoran ternak, dapat meningkatkan kesuburan tanah dan mengatasi kekurangan unsur hara di tanah gambut. Salah satu kotoran ternak yang sering digunakan adalah pupuk kotoran ayam. Pupuk kotoran ayam mengandung unsur hara nitrogen (N) $(3,21 \%)$, fosfor (P) $(3,23 \%)$, yang tinggi dibandingkan pupuk organik lain (Yusnaini, 2009). Penelitian yang dilakukan Saukani (2015), menyebutkan bahwa penggunaan pupuk organik kotoran ayam 30 ton/ha mampu meningkatkan pertumbuhan tanaman dengan meningkatkan unsur hara makro $\mathrm{N}, \mathrm{P}$, dan $\mathrm{K}$ yang sangat berperan dalam fase generatif dan vegetatif tanaman pada tanah gambut.

Penggunaan mikoriza pada kedelai menurut Suherman et al. (2012) meningkatkan pertumbuhan terhadap tinggi tanaman, jumlah daun, berat biji pertanaman sampel dan berat 1000 biji kedelai dengan konsentrasi mikoriza 8 g/polibag. Glomus agregatum salah satu mikoriza yang banyak digunakan sebagai pupuk hayati untuk pertumbuhan tanaman terbukti dapat meningkat- 
kan pertumbuhan tanaman. Penelitian yang dilakukan Leskona et al. (2013) bahwa penggunaan $G$. agregatum dapat meningkatkan pertumbuhan tanaman jagung ditandai dengan pertambahan tinggi, berat basah, serta berat kering tanaman. Penggunaan jamur mikoriza juga berpengaruh terhadap pertumbuhan.

Kombinasi pemberian pupuk kotoran ayam dan mikoriza diduga dapat meningkatkan kolonisasi akar tanaman di dalam tanah sehingga diharapkan mampu meningkatkan pertumbuhan kedelai. Penelitian kombinasi antara pupuk kotoran ayam dan mikoriza terhadap kedelai sebelumnya telah dilakukan Buhaira (2013), menunjukkan penggunaan konsentrasi kompos kotoran ayam dan dosis mikoriza memberikan pengaruh nyata terhadap tinggi tanaman dan berat kering akar.

Berdasarkan latar belakang penggunaan jamur mikoriza G.agregatum dan pupuk kotoran ayam untuk pertumbuhan tanaman kedelai var. Sinabung belum pernah dilakukan maka penting dilakukan penelitian untuk melihat pertumbuhan tanaman kedelai varietas Sinabung pada media tanah gambut.

\section{BAHAN DAN METODE}

\section{Waktu dan Tempat}

Penelitian ini dilaksanakan selama 4 bulan, dari bulan Januari 2019 hingga April 2019. Penelitian dilakukan di Rumah Kaca Program Studi Biologi, Jurusan Biologi, Fakultas Matematika dan Ilmu Pengetahuan Alam, Universitas Tanjungpura, Pontianak. Analisis tanah, kotoran ayam, dan kebutuhan kapur dilakukan di Laboratorium Kimia dan Kesuburan Tanah Fakultas Pertanian Universitas Tanjungpura Pontianak.

\section{Bahan dan Alat}

Bahan yang digunakan pada penelitian ini adalah air, tanah gambut, kotoran ayam dari peternakan ayam Rasau Jaya, EM4, gula merah, arang sekam, zeolite jamur mikoriza dari BIOTROP Bogor, kapur dolomit, dan biji kedelai (Glycine max. L var. Sinabung) dari Unit Pengawasan dan Sertifikasi Benih Tanaman Pangan Dan Hortikultura Kalimantan Barat

Alat yang digunakan pada penelitian ini adalah ayakan, polybag dengan ukuran $23 \mathrm{~cm} \times 13 \mathrm{~cm}$, sendok semen, cangkul, sprayer, oven, ember, timbangan digital, Termohigrometer, penggaris, pisau, kamera, terpal atau karung beras, dan alat alat tulis

\section{Rancangan Penelitian}

Rancangan yang digunakan pada penelitian ini adalah Rancangan Acak Lengkap (RAL) faktorial dengan 2 faktor perlakuan yaitu faktor pertama mikoriza (M) dan faktor kedua pupuk kotoran ayam $(\mathrm{P})$, setiap perlakuan diulang sebanyak 4 kali sehingga diperoleh 64 unit percobaan.

\section{Prosedur kerja}

\section{Persiapan Media Tanam}

Tanah yang digunakan adalah tanah gambut yang diambil dari kedalaman 0-20 cm, lalu dikomposkan, kemudian dikeringanginkan / diinkubasi selama 2 minggu, dibersihkan dari sampah serta sisa-sisa tanaman. Tanah diayak menggunakan ayakan kawat berdiameter $5 \mathrm{~mm}$. tanah hasil ayakan dicampur dengan kapur dolomit sebanyak $103 \mathrm{~g} /$ polibag berdasarkan perhitungan kebutuhan kapur/polibag. Selanjutnya dimasukkan ke dalam polibag, masing-masing polibag diisi dengan 1,6 kg. (Merdekawati et al., 2014). Tanah dimasukkan ke dalam plastik wayang, selanjutnya disterilisasi menggunakan autoklaf dengan temperatur $121^{\circ} \mathrm{C}$ dan tekanan 1 atm selama 15 menit (Cahyani, 2009).

\section{Pembuatan dan Pemberian Pupuk Kotoran Ayam}

Kotoran ayam dikeringanginkan untuk menghindari tumbuhnya jamur (Ishak et al., 2013). Pembuatan kompos kotoran ayam yaitu kotoran ayam, arang sekam, dolomit dan EM4 dicampur dengan perbandingan 6:3:1:1. Kotoran ayam, arang sekam dan dolomit kemudian dimasukkan ke dalam wadah dan disiram dengan campuran EM4 dan gula merah dengan perbandingan 1:1. Setelah itu disiram dengan air kurang lebih 2L untuk menjaga kelembaban kompos, kemudian ditutup dengan terpal atau karung, setelah 15 hari kompos ayam dapat digunakan (Iliana, 2017).

Pemberian Mikoriza dan Pupuk Kotoran Ayam Pemberian mikoriza pada media tanam sesuai dengan dosis yang diujikan, diberikan pada saat biji kedelai (Malik et al., 2016). Pemberian pupuk kotoran ayam dilakukan sesuai dengan perlakuan. Setelah itu tanah dicampur dan diaduk dengan pupuk kotoran ayam, lalu dibiarkan selama satu minggu sebelum tanam (Marlina et al., 2015).

\section{Penanaman Kedelai}

Penanaman dilakukan dengan menebar biji kedelai sebanyak 5 biji per polibag pada pagi atau sore hari, hasil semaian yang pertumbuhannya baik dipilih 1 tanaman sebagai tanaman uji dan sisanya dicabut. Tanaman yang dipilih sebagai 
tanaman uji, memiliki tinggi sekitar $10 \mathrm{~cm}$ dengan 3 helaian daun atau lebih, waktu penyemaian dilakukan 14 hari (Bandini \& Azis, 2004).

\section{Pemeliharaan Tanaman}

Pemeliharaan tanaman meliputi penyiraman yang dilakukan 1 kali sehari, yaitu pada pagi hari pukul 07.00-09.00 WIB atau pada sore hari pukul 15.0017.00 WIB. Penyiangan gulma dilakukan dengan cara mencabut gulma yang tumbuh di sekitar tanaman, pemeliharaan tanaman dilakukan hingga fase vegetatif selama 35 hari setelah tanam (HST) (Bandini \& Azis, 2004).

\section{Pengamatan Lingkungan dan Kesuburan Tanah}

Pengamatan terhadap kondisi lingkungan disekitar tanaman serta parameter kesuburan media tanam meliputi: suhu udara $\left({ }^{0} \mathrm{C}\right)$, kelembapan udara relatif (\%), dan analisis tanah.

Pengukuran suhu udara dan kelembaban dilakukan 1 minggu sekali dengan menggunakan termometer dan higrometer yang dilakukan pada pagi hari pukul 06.00-08.00 WIB, siang hari pukul 12.00-13.00 WIB dan sore hari pukul 16.00-18.00 WIB serta tanah pada awal penelitian sebelum penanaman meliputi $\mathrm{pH}$, kandungan $\mathrm{N}, \mathrm{P}, \mathrm{K}, \mathrm{C}$ organik, fisika dan kimia tanah, dan nisbah $\mathrm{C} / \mathrm{N}$.

\section{Parameter Pengamatan}

Pengamatan dilakukan selama fase vegetatif yaitu 35 hari setelah tanam (HST). parameter pertumbuhan yang diamati yaitu :

\section{a. Tinggi tanaman $(\mathrm{cm})$}

Pengukuran tinggi tanaman dilakukan pada akhir penelitian dengan menggunakan penggaris, pengukuran dimulai dari pangkal batang sampai titik tumbuh pucuk.

b. Berat basah tanaman (gram)

Berat basah tanaman diukur pada akhir penelitian, berat basah diukur dengan menimbang tanaman dalam keadaan segar dengan menggunakan timbangan analitik.

\section{c. Berat kering tanaman (gram)}

Berat kering tanaman diukur pada akhir penelitian, yaitu tanaman dikeringkan dalam oven dengan suhu $60-70^{\circ} \mathrm{C}$. hingga mendapatkan berat kering yang konstan, lalu ditimbang menggunakan timbangan analitik.

\section{d. Jumlah daun}

Penghitungan jumlah daun dilakukan dengan menghitung keseluruhan jumlah daun majemuk yang ada pada tanaman tersebut.

\section{Analisis Data}

Data pertumbuhan dianalisis dengan ANOVA dua jalur taraf uji 5\% menggunakan SPSS 18. Bila terdapat pengaruh nyata dilanjutkan dengan uji Duncan pada taraf uji 5\% (Gaspers, 1991).

\section{HASIL DAN PEMBAHASAN}

\section{Hasil}

\section{Tinggi Tanaman}

Berdasarkan analisis diketahui bahwa perlakuan pupuk kotoran ayam berpengaruh nyata terhadap tinggi tanaman kedelai $\left(\mathrm{F}_{15,48}=11,182, \mathrm{p}=0,000\right.$; ANOVA). Namun, pemberian jamur mikoriza $\left(\mathrm{F}_{15,48}=0,849, \mathrm{p}=0,474 ;\right.$ ANOVA $)$ serta kombinasi kedua perlakuan $\left(\mathrm{F}_{15,48}=0,591, \mathrm{p}=\right.$ 0,798; ANOVA) tidak berpengaruh nyata.

Tabel 1. Rerata tinggi tanaman $(\mathrm{cm})$ kedelai dengan perlakuan pupuk kotoran ayam

\begin{tabular}{cc}
\hline $\begin{array}{c}\text { Pupuk Kotoran Ayam } \\
\text { (ton/ha) }\end{array}$ & Tinggi Tanaman $(\mathrm{cm})$ \\
\hline P1 (0) & $65,20^{\mathrm{a}}$ \\
P2 (5) & $74,86^{\mathrm{b}}$ \\
P3 (10) & $73,71^{\mathrm{b}}$ \\
P4 (15) & $73,23^{\mathrm{b}}$ \\
\hline
\end{tabular}

Keterangan: Angka yang diikuti oleh huruf yang sama menunjukkan hasil yang tidak berbeda nyata

Hasil analisis menunjukkan bahwa perlakuan pupuk kotoran ayam pada konsentrasi 5, 10, dan 15 ton/ha berbeda nyata dengan kontrol tapi tidak berbeda nyata antar perlakuan. Tinggi tanaman tertinggi ditunjukkan pada konsentrasi pupuk kotoran ayam 5 ton/ha yaitu 74,86 cm (Tabel 1).

Tabel 2. Rerata tinggi tanaman $(\mathrm{cm})$ kedelai dengan perlakuan jamur mikoriza

\begin{tabular}{cc}
\hline Jamur Mikoriza $(\mathrm{g})$ & Tinggi Tanaman $(\mathrm{cm})$ \\
\hline M1 (0) & 70.23 \\
M2 (5) & 71.40 \\
M3 (10) & 72.29 \\
M4 (15) & 73.07 \\
\hline
\end{tabular}

Hasil analisis menunjukkan bahwa perlakuan jamur mikoriza pada konsentrasi 5, 10, dan 15 $\mathrm{g} /$ polybag tidak berbeda nyata dengan kontrol dan tidak berbeda nyata antar perlakuan. Tinggi tanaman tertinggi ditunjukkan pada konsentrasi jamur mikoriza $15 \mathrm{~g} /$ polibag yaitu $73,07 \mathrm{~cm}$ (Tabel 2).

Tabel 3. Rerata tinggi tanaman (g) kedelai dengan perlakuan kombinasi jamur mikoriza dan pupuk kotoran ayam

\begin{tabular}{lllll}
\hline Jamur & \multicolumn{4}{l}{ P. Kotoran Ayam (ton/ha) } \\
\cline { 2 - 5 } Mikoriza (g) & P1 (0) & P2 (5) & P3 (10) & P4 (15) \\
\hline M1 (0) & 62.95 & 72.77 & 70.95 & 74.27 \\
M2 (5) & 64.67 & 77.07 & 70.90 & 72.97 \\
M3 (10) & 66.75 & 73.90 & 75.45 & 73.07 \\
M4 (15) & 66.42 & 75.72 & 77.55 & 72.60 \\
\hline
\end{tabular}


Hasil analisis menunjukkan bahwa kombinasi perlakuan jamur mikoriza dan pupuk kotoran ayam tidak berpengaruh nyata terhadap tinggi tanaman. Tinggi tanaman tertinggi ditunjukkan pada kombinasi konsentrasi jamur mikoriza 15 g/polybag dengan 10 ton/ha pupuk kotoran ayam yaitu 77,55 cm (Tabel 3).

\section{Jumlah Daun}

Berdasarkan analisis ANOVA diketahui bahwa perlakuan pupuk kotoran ayam berpengaruh nyata terhadap jumlah daun kedelai $\left(\mathrm{F}_{15,48}=24,041, \mathrm{p}=\right.$ 0,000 ; ANOVA) namun jamur mikoriza $\left(\mathrm{F}_{15,48}=\right.$ $0,762, \mathrm{p}=0,521$; ANOVA) serta kombinasi kedua perlakuan $\left(\mathrm{F}_{15,48}=0,870, \mathrm{p}=0,558\right.$; ANOVA $)$ tidak berpengaruh nyata.

Tabel 4. Rerata jumlah daun (helai) kedelai dengan perlakuan pupuk kotoran ayam

\begin{tabular}{cc}
\hline $\begin{array}{c}\text { Pupuk Kotoran Ayam } \\
\text { (ton/ha) }\end{array}$ & Jumlah Daun (helai) \\
\hline P1 (0) & $10,43^{\mathrm{a}}$ \\
P2 (5) & $16,62^{\mathrm{b}}$ \\
P3 (10) & $17,31^{\mathrm{b}}$ \\
P4 (15) & $18,87^{\mathrm{b}}$ \\
\hline
\end{tabular}

Keterangan: Angka yang diikuti oleh huruf yang sama menunjukkan hasil yang tidak berbeda nyata

Hasil analisis menunjukkan bahwa perlakuan pupuk kotoran ayam pada konsentrasi 5, 10, dan 15 ton/ha berbeda nyata dengan kontrol namun tidak berbeda nyata antar perlakuan. Jumlah daun terbanyak ditunjukkan pada konsentrasi pupuk kotoran ayam 15 ton/ha yaitu 18,87 helai (Tabel 4).

Tabel 5. Rerata jumlah daun (helai) kedelai dengan perlakuan jamur mikoriza

\begin{tabular}{cc}
\hline Jamur Mikoriza $(\mathrm{g})$ & Jumlah Daun (helai) \\
\hline M1 (0) & 15.00 \\
M2 (5) & 16.43 \\
M3 (10) & 16.25 \\
M4 (15) & 15.56 \\
\hline
\end{tabular}

Hasil analisis menunjukkan bahwa perlakuan jamur mikoriza pada konsentrasi 5, 10, dan 15 g/polibag tidak berbeda nyata dengan kontrol dan tidak berbeda nyata antar perlakuan. Jumlah daun terbanyak ditunjukkan pada konsentrasi jamur mikoriza $5 \mathrm{~g} /$ polibag yaitu 16,43 helai (Tabel 5).

Tabel 6. Rerata jumlah daun (g) kedelai dengan perlakuan kombinasi jamur mikoriza dan pupuk kotoran ayam

\begin{tabular}{lcccc}
\hline Jamur & \multicolumn{3}{l}{ P. Kotoran Ayam (ton/ha) } \\
\cline { 2 - 5 } Mikoriza (g) & P1 (0) & P2 (5) & P3 (10) & P4 (15) \\
\hline M1 (0) & 10.00 & 16.50 & 15.50 & 18.00 \\
M2 (5) & 11.25 & 19.00 & 17.25 & 18.25 \\
M3 (10) & 11.25 & 15.50 & 19.50 & 18.75 \\
M4 (15) & 9.25 & 15.50 & 17.00 & 20.50 \\
\hline
\end{tabular}

Hasil analisis menunjukkan bahwa kombinasi perlakuan jamur mikoriza dan pupuk kotoran ayam tidak berpengaruh nyata terhadap jumlah daun. Jumlah daun terbanyak ditunjukkan pada kombinasi konsentrasi jamur mikoriza 15 $\mathrm{g} /$ polibag dan 15 ton/ha pupuk kotoran ayam yaitu 20,50 cm (Tabel 6).

\section{Berat Basah}

Berdasarkan analisis ANOVA diketahui bahwa perlakuan jamur mikoriza $\left(\mathrm{F}_{15,48}=10,518, \mathrm{p}=\right.$ 0,000; ANOVA) dan perlakuan pupuk kotoran ayam $\left(\mathrm{F}_{15,48}=9,964, \mathrm{p}=0,000\right.$; ANOVA $)$ serta kombinasi antara keduanya $\left(\mathrm{F}_{15,48}=3,156, \mathrm{p}=\right.$ 0,005 ; ANOVA) memberikan pengaruh nyata terhadap berat basah kedelai.

Tabel 7. Rerata berat basah (g) kedelai dengan perlakuan pupuk kotoran ayam

\begin{tabular}{cc}
\hline $\begin{array}{c}\text { Pupuk Kotoran Ayam } \\
\text { (ton/ha) }\end{array}$ & Berat Basah (g) \\
\hline P1 (0) & $50,46^{\mathrm{a}}$ \\
P2 (5) & $65,22^{\mathrm{b}}$ \\
P3 (10) & $67,69^{\mathrm{b}}$ \\
P4 (15) & $71,91^{\mathrm{b}}$ \\
\hline
\end{tabular}

Keterangan: Angka yang diikuti oleh huruf yang sama menunjukkan hasil yang tidak berbeda nyata

Hasil analisis menunjukkan bahwa perlakuan pupuk kotoran ayam pada konsentrasi 5, 10, dan 15 ton/ha berbeda nyata dengan kontrol tapi tidak berbeda nyata antar perlakuan. Berat basah tertinggi ditunjukkan pada konsentrasi pupuk kotoran ayam 15 ton/ha yaitu 71,91 g (Tabel 7).

Tabel 8. Rerata berat basah (g) kedelai dengan perlakuan jamur mikoriza

\begin{tabular}{cc}
\hline Jamur Mikoriza $(\mathrm{g})$ & Berat Basah $(\mathrm{g})$ \\
\hline M1 (0) & $73,82^{\mathrm{b}}$ \\
M2 (5) & $69,70^{\mathrm{b}}$ \\
M3 (10) & $53,15^{\mathrm{a}}$ \\
M4 (15) & $58,61^{\mathrm{a}}$ \\
\hline
\end{tabular}

Keterangan: Angka yang diikuti oleh huruf yang sama menunjukkan hasil yang tidak berbeda nyata

Hasil analisis menunjukkan bahwa pemberian tanpa perlakuan jamur mikoriza tidak berbeda nyata dengan perlakuan penggunaan jamur mikoriza $5 \mathrm{~g}$. Perlakuan jamur mikoriza dengan konsentrasi 10 dan 15 berpengaruh nyata dengan kontrol, tapi tidak berbeda nyata antar perlakuan. (Tabel 8).

Berdasarkan analisis ANOVA menunjukkan bahwa kombinasi perlakuan M3P2, M3P3, M3P4, M4P2, dan M4P3 tidak berbeda nyata terhadap kontrol (M1P1) (Tabel 4.5). Perlakuan kombinasi 
M2P2, M2P3, M2P4 dan M4P4 berbeda nyata terhadap kontrol (Tabel 9). Berdasarkan hasil analisis kombinasi pupuk kotoran ayam dan mikoriza tertinggi adalah mikoriza $5 \mathrm{~g}$ dan pupuk kotoran ayam 5 ton/ha yaitu perlakuan M2P2 dengan 79,66 g (Tabel 9).

Tabel 9. Rerata berat basah (g) kedelai dengan perlakuan kombinasi jamur mikoriza dan pupuk kotoran ayam

\begin{tabular}{lcccc}
\hline Jamur & \multicolumn{4}{l}{ P. Kotoran Ayam (ton/ha) } \\
\cline { 2 - 5 } $\begin{array}{l}\text { Mikoriza } \\
\text { (g) }\end{array}$ & P1 (0) & P2 (5) & P3 (10) & P4 (15) \\
\hline M1 (0) & $44,25^{\mathrm{a}}$ & $80,78^{\mathrm{ef}}$ & $80,48^{\mathrm{ef}}$ & $89,79^{\mathrm{f}}$ \\
M2 (5) & $49,94^{\mathrm{ab}}$ & $79,66^{\mathrm{ef}}$ & $71,16^{\mathrm{cdef}}$ & $78,03^{\mathrm{def}}$ \\
M3 (10) & $55,15^{\mathrm{abc}}$ & $47,58^{\mathrm{a}}$ & $58,96^{\mathrm{abc}}$ & $50,92^{\mathrm{ab}}$ \\
M4 (15) & $52,50^{\mathrm{abc}}$ & $52,87^{\mathrm{abc}}$ & $60,17^{\mathrm{abc}}$ & $68,91^{\mathrm{bcd}}$ \\
\hline
\end{tabular}

Keterangan: Angka yang diikuti oleh huruf yang sama menunjukkan hasil yang tidak berbeda nyata

\section{Berat Kering}

Berdasarkan analisis ANOVA diketahui bahwa perlakuan pupuk organik mikoriza $\left(\mathrm{F}_{15,48}=5,650\right.$, $\mathrm{p}=0,002$; ANOVA) dan perlakuan pupuk kotoran ayam $\left(\mathrm{F}_{15,48}=18,428, \mathrm{p}=0,000 ;\right.$ ANOVA $)$ serta kombinasi antara keduanya $\left(\mathrm{F}_{15,48}=9,465, \mathrm{p}=\right.$ 0,005 ; ANOVA) memberikan pengaruh nyata terhadap berat kering kedelai.

Tabel 10. Rerata berat kering (g) kedelai dengan perlakuan pupuk kotoran ayam

\begin{tabular}{cc}
\hline $\begin{array}{c}\text { Pupuk Kotoran Ayam } \\
\text { (ton/ha) }\end{array}$ & Berat Kering (g) \\
\hline P1 (0) & $50,46^{\mathrm{a}}$ \\
P2 (5) & $65,22^{\mathrm{b}}$ \\
P3 (10) & $67,69^{\mathrm{b}}$ \\
P4 (15) & $71,91^{\mathrm{b}}$ \\
\hline
\end{tabular}

Keterangan: Angka yang diikuti oleh huruf yang sama menunjukkan hasil yang tidak berbeda nyata

Hasil analisis menunjukkan bahwa perlakuan pupuk kotoran ayam pada konsentrasi 5, 10, dan 15 ton/ha berbeda nyata dengan kontrol tapi tidak berbeda nyata antar perlakuan. Berat kering tertinggi ditunjukkan pada konsentrasi pupuk kotoran ayam 15 ton/ha yaitu 26,03 gr (Tabel 10).

Tabel 11. Rerata berat kering (g) kedelai dengan perlakuan jamur mikoriza

\begin{tabular}{cc}
\hline Jamur Mikoriza $(\mathrm{g})$ & Berat Kering $(\mathrm{g})$ \\
\hline M1 (0) & $73,82^{\mathrm{b}}$ \\
M2 (5) & $69,70^{\mathrm{b}}$ \\
M3 (10) & $53,15^{\mathrm{a}}$ \\
M4 (15) & $58,61^{\mathrm{a}}$ \\
\hline
\end{tabular}

Keterangan: Angka yang diikuti oleh huruf yang sama menunjukkan hasil yang tidak berbeda nyata
Hasil analisis menunjukkan perlakuan jamur mikoriza pada konsentrasi 5, 10 dan 15 g berbeda nyata dengan kontrol, tapi tidak berbeda nyata antar perlakuan. Berat kering paling tinggi terdapat pada konsentrasi jamur mikoriza 0 gr yaitu 26,41 g (Tabel 11).

Tabel 12. Rerata berat kering (g) kedelai dengan perlakuan kombinasi jamur mikoriza dan pupuk kotoran ayam

\begin{tabular}{lcccc}
\hline Jamur & \multicolumn{4}{l}{ P. Kotoran Ayam (ton/ha) } \\
\cline { 2 - 5 } Mikoriza (g) & P1 (0) & P2 (5) & P3 (10) & P4 (15) \\
\hline M1 (0) & $9,09^{\mathrm{a}}$ & $26,70^{\mathrm{e}}$ & $28,27^{\mathrm{e}}$ & $41,59^{\mathrm{f}}$ \\
M2 (5) & $17,97^{\mathrm{b}}$ & $26,41^{\text {de }}$ & $25,34^{\mathrm{cde}}$ & $18,57^{\mathrm{bc}}$ \\
M3 (10) & $19,20^{\mathrm{bc}}$ & $18,70^{\mathrm{bc}}$ & $27,16^{\mathrm{e}}$ & $17,47^{\mathrm{b}}$ \\
M4 (15) & $15,28^{\text {ab }}$ & $22,25^{\text {bcde }}$ & $19,44^{\text {bcd }}$ & $26,51^{\text {de }}$ \\
\hline
\end{tabular}

Keterangan: Angka yang diikuti oleh huruf yang sama menunjukkan hasil yang tidak berbeda nyata

Berdasarkan analisis ANOVA menunjukkan bahwa kombinasi perlakuan M2P2, M2P3, M2P4, M3P2, M3P3, M3P4, M4P2, M4P3, dan M4P4 berbeda nyata terhadap kontrol (M1P1) (Tabel 4.8). Berdasarkan hasil pengamatan berat kering kedelai, kombinasi pupuk kotoran ayam dan mikoriza yang memberikan pengaruh terbaik adalah mikoriza $10 \mathrm{~g}$ dan pupuk kotoran ayam 10 ton/ha yaitu M3P3 dengan 27,16 g (Tabel 12).

\section{Pembahasan}

Berdasarkan hasil yang diperoleh penggunaan pupuk kotoran ayam secara tunggal pada parameter pengamatan tinggi tanaman dan jumlah daun berpengaruh nyata terhadap pertumbuhan tanaman kedelai (Tabel 1 \& Tabel 4). Tinggi tanaman yang diberi pupuk kotoran ayam secara tunggal rata rata menghasilkan pertumbuhan tinggi tanaman tertinggi. Penggunaan pupuk kotoran ayam 5 ton/ha menghasilkan tinggi tanaman sebesar 74,86 cm (Tabel 1), sedangkan penggunaan pupuk kotoran ayam 15 ton/ha menghasilkan jumlah daun sebanyak 18,87 helai (Tabel 4). Pupuk kotoran ayam diduga memiliki unsur hara makro fosfor $(\mathrm{P})$ dan nitrogen $(\mathrm{N})$ yang mencukupi untuk pertumbuhan kedelai. Pertumbuhan kedelai sangat dipengaruhi oleh unsur hara makro dan mikro pada fase awal pertumbuhannya. Menurut Suryati et al. (2009), penyerapan hara oleh tanaman semakin meningkat sejalan dengan laju pertumbuhan vegetatif, dimulai dari fase perkecambahan sampai awal berbunga.

Unsur hara $\mathrm{N}$ dan $\mathrm{P}$ pada kotoran ayam yang diserap oleh tumbuhan, akan diserap dalam bentuk unsur hara yang tersedia. Menurut Salisbury \& Ross (1995), unsur hara N diserap oleh tumbuhan dalam bentuk ion yaitu ion nitrat 
$\left(\mathrm{NO}_{3}{ }^{-}\right)$dan ammonium $\left(\mathrm{NH}_{4}^{+}\right)$. Penyerapan ion nitrat $\left(\mathrm{NO}_{3}{ }^{-}\right)$dan ammonium $\left(\mathrm{NH}_{4}{ }^{+}\right)$ memungkinkan tumbuhan untuk membentuk berbagai senyawa nitrogen, terutama protein. $\mathrm{pH}$ tanah gambut yang rendah, membuat ion $\mathrm{NH}_{4}{ }^{+}$ menjadi sumber nitrogen yang lebih besar dibandingkan dengan ion $\mathrm{NO}_{3}^{-}$. Menurut Salisbury \& Ross (1995), unsur hara P diserap terutama oleh tanaman sebagai anion fosfat valensi satu $\left(\mathrm{H}_{2} \mathrm{PO}_{4}^{-}\right)$dan diserap lebih lambat dalam bentuk anion valensi dua $\left(\mathrm{HPO}_{4}{ }^{2-}\right) . \mathrm{pH}$ tanah juga mengendalikan kedua anion ini. $\mathrm{H}_{2} \mathrm{PO}_{4}{ }^{-}$ tersedia pada $\mathrm{pH}$ di bawah 7, dan $\mathrm{HPO}_{4}{ }^{2-}$ di atas 7 .

Tinggi tanaman dan jumlah daun erat kaitan nya dengan unsur hara N. Lingga (2010), menyatakan bahwa unsur hara $\mathrm{N}$ sangat dibutuhkan tanaman untuk sintesa protein, terutama pada titik titik tumbuh tanaman sehingga mempercepat proses pembelahan sel dan pemanjangan sel pada titik tumbuh yang akan memengaruhi pertambahan tinggi tanaman. Ketersedian unsur hara $\mathrm{N}$ di dalam tanah juga dapat memmengaruhi jumlah daun yang terbentuk. Lakitan (1995), menyatakan jika kandungan hara dalam tanah cukup tersedia maka sebagian besar asimilat dialokasikan untuk pembentukan daun yang mengakibatkan jumlah daun bertambah.

Berdasarkan hasil penelitian yang didapat, pemberian pupuk kotoran ayam 5 ton/ha diduga sudah cukup memberikan pengaruh terhadap pertumbuhan tinggi dan jumlah daun (Tabel 1 \& Tabel 4). Pupuk organik kotoran ayam diduga juga dapat memperbaiki sifat fisik tanah gambut. Tufaila (2013), menyatakan bahwa semakin tinggi dosis pupuk organik yang digunakan maka jumlah hara yang memengaruhi karakterisitik tanah menjadi semakin tinggi sehingga memungkinkan terjadinya peningkatan $\mathrm{pH}$ tanah, kandungan $\mathrm{N}$ total, dan $\mathrm{P}$ tersedia di dalam tanah. Menurut Sidabutar (2006), pupuk kotoran ayam mampu meningkatkan unsur hara $\mathrm{N}$ di dalam tanah yang masam, bahan organik pada kotoran ayam merupakan sumber nutrisi bagi mikroorganisme tanah termasuk bakteri pengikat nitrogen.

Media tanah gambut yang digunakan memiliki tingkat kesuburan yang rendah serta memiliki kemasaman yang tinggi. Pupuk kotoran ayam dapat memperbaiki sifat fisik dari tanah dan meningkatkan ketersediaan unsur hara di dalam tanah. Menurut Mayadewi (2007), pemberian pupuk kandang ayam dapat memperbaiki sifat fisik tanah menjadi lebih gembur dan menambah tersedianya unsur hara serta pertumbuhan mikroorganisme di dalam tanah. Marlina (2015), menyatakan bahwa kondisi sifat fisik tanah yang remah dan gembur menyebabkan perkembangan yang baik pada akar sehingga meningkatkan penyerapan unsur hara dan air yang diperlukan tanaman.

Kombinasi pemberian jamur mikoriza dan pupuk kotoran ayam pada tanaman kedelai pada parameter pengamatan tinggi tanaman dan jumlah daun tidak berbeda nyata (Tabel $3 \&$ Tabel 6). Parameter pengamatan tinggi tanaman dan jumlah daun kombinasi perlakuan jamur mikoriza dan pupuk kotoran ayam tidak berbeda nyata, dapat disebabkan oleh sudah tersedianya unsur hara $\mathrm{N}$ dalam tanah dengan jumlah yang cukup sehingga peran mikoriza menjadi lebih sedikit. Novizan (2002), menyatakan bahwa unsur $\mathrm{N}$ pada tanaman berfungsi membentuk asam amino dan protein yang dimanfaatkan dalam memacu pertumbuhan fase vegetatif. Mikoriza diduga juga pula belum masuk kedalam fase mengkolonisasi akar tanaman inang, dalam perkembangannya mikoriza melalui beberapa tahap sebelum masuk ke infeksi akar tanaman inang, sehingga menyebabkan tidak berpengaruhnya mikoriza terhadap tinggi tanaman dan jumlah daun.

Berdasarkan hasil yang didapatkan perlakuan jamur mikoriza (Tabel 8 \& 11) dan pupuk kotoran ayam (Tabel $7 \&$ Tabel 10) berpengaruh nyata terhadap berat basah dan berat kering tanaman kedelai. Hal ini diduga unsur hara $\mathrm{P}$ dalam pupuk kotoran ayam dan kemampuan mikoriza dalam menyerap unsur hara $\mathrm{P}$, mampu memenuhi pertumbuhan akar sehingga akar memiliki kemampuan baik dalam menyerap air dan hara. Berdasarkan hasil pengamatan berat basah, pupuk kotoran ayam berpengaruh terhadap pertumbuhan kedelai (Tabel 7). Berat basah dipengaruhi oleh jumlah dan serapan air dan hara pada suatu tanaman. Peran air bagi tanaman menurut Salisbury \& Ross (1995), sebagai komponen penting dalam proses fotosintesis dan respirasi tanaman. Proses penyerapan air sangat berkaitan erat dengan sistem perakaran.

Berdasarkan hasil pengamatan berat kering, pupuk kotoran ayam berpengaruh terhadap pertumbuhan kedelai (Tabel 10). Berat kering tanaman salah satunya dipengaruhi oleh proses fotosintesis, dan berkaitan dengan pertumbuhan jumlah daun, semakin banyak jumlah daun maka semakin banyak fotosintat yang dihasilkan dari proses fotosintesis. Blair (1993), menambahkan semakin tinggi berat kering tanaman yang dihasilkan, menandakan bahwa pertumbuhan semakin baik dan unsur hara yang diserap semakin banyak. 
Peningkatan ketersediaan hara akan berpengaruh terhadap peningkatan serapan hara sehingga biomasssa tanaman akan menjadi lebih baik.

Berat kering tanaman kedelai selain dipengaruhi oleh adanya penambahan massa dari hasil fotosintesis juga dipengaruhi unsur hara yang diserap tanaman. Novizan (2002), menyatakan bahwa unsur hara makro essensial berupa $\mathrm{N}, \mathrm{P}$, dan $\mathrm{K}$ berperan penting dalam pembelahan sel dan pemanjangan sel, semakin bertambahnya jumlah sel maka berat kering massa tanaman juga semakin meningkat. Kandungan unsur hara makro essensial yang dimiliki pupuk kotoran ayam diduga dapat meningkatkan penambahan massa pada tanaman kedelai.

Kombinasi pemberian jamur mikoriza dan pupuk kotoran ayam pada pengamatan berat basah dan berat kering, berpengaruh nyata terhadap kontrol dengan faktor mikoriza yang lebih sedikit pada berat basah yaitu 0 dan 5 g mikoriza (Tabel $9 \&$ Tabel 12). Hal ini diduga penggunaan pupuk kotoran ayam yang memiliki unsur hara $\mathrm{P}$ tinggi dimanfaatkan oleh jamur mikoriza yang memiliki kemampuan menyerap unsur hara P. Penggunaan mikoriza memproduksi jaringan hifa eksternal yang tumbuh secara ekspansif, sehingga meningkatkan kapasitas akar dalam penyerapan air dan unsur hara, terutama unsur P. Tingginya air dan unsur hara yang terserap oleh tanaman membuat berat basah dan berat kering menjadi meningkat (Sastrahidayat, 2011)

Menurut Musfal (2010), berat basah dan kering tanaman mencerminkan hasil penyerapan air dan fotosintat yang dihasilkan oleh tanaman. Semakin tingginya serapan air dan unsur hara pada tanaman menyebabkan proses metabolisme dan fotosintesis semakin baik. Lana (2009), menambahkan bahwa banyaknya serapan air dan unsur hara akan menjamin lebih baiknya proses metabolisme tanaman seperti proses transportasi dan alokasi fotosintat.

Penggunaan $5 \mathrm{~g}$ mikoriza dan 5 ton/ha kotoran ayam rata rata memiliki hasil terbaik pada berat basah dan berat kering (Tabel 9 \& Tabel 12). Lakitan (2012), menambahkan bahwa penggunaan mikoriza relatif lebih efektif apabila dilakukan pada tanah yang kurang subur. Penelitian Fikrinda (2011), menambahkan bahan organik seperti pupuk kandang ayam yang lebih sedikit dapat meningkatkan aktivitas mikoriza pada tanah-tanah yang memiliki bahan organik rendah. Kebutuhan pupuk kandang ayam dapat dikurangi dengan adanya penambahan mikoriza pada media tanam.
Penggunaan mikoriza secara tunggal tidak memberikan pengaruh nyata terhadap parameter pengamatan yang dilakukan. Hasil analisis yang didapatkan menunjukkan penggunaan mikoriza secara tunggal tidak berbeda nyata dengan kontrol yang diujikan pada parameter pengamatan tinggi tanaman dan jumlah daun (Tabel $2 \&$ Tabel 5). Hal ini dapat disebabkan waktu perkecambahan mikoriza dan waktu pertumbuhan tanaman inang yang kurang sesuai. Mikoriza dalam perkembangannnya, memerlukan beberapa tahap sebelum masuk ke proses infeksi ke akar tanaman inang. Menurut Norland (1993), spora mikoriza memerlukan waktu 3-4 minggu untuk berkecambah dan menginfeksi akar. Berdasarkan Norland (1993), maka penggunaan mikoriza dapat efektif pada waktu 3-4 minggu, dan pertumbuhan kedelai yang memerlukan waktu 35 HST, mikoriza masih dalam tahap perkembangan, sehingga pada parameter tinggi tanaman dan jumlah daun masih belum efektif penggunaan mikoriza secara tunggal.

Penggunaan mikoriza secara tunggal tidak berpengaruh nyata, diduga juga dapat disebabkan oleh derajat infeksi akar yang masih rendah. Penelitian yang dilakukan Hadianur (2016), derajat infeksi mikoriza terhadap pertumbuhan dan hasil tanaman tomat, pada konsentrasi $10 \mathrm{~g}$ dapat meningkatkan produksi tanaman tomat sebesar 144 ton/ha dibanding kontrol. Prasasti (2013), menambahkan bahwa infeksi mikoriza yang terdapat pada akar tanaman dapat menyebabkan pertumbuhan pada tanaman, yaitu mikoriza akan menggantikan peran akar dengan hifa eksternalnya dalam menyerap air dan unsur hara dalam tanah.

\section{DAFTAR PUSTAKA}

Bandini, Y, \& Aziz, N, 2004, Bayam, Penebar Swadaya, Jakarta

Blair, 1993, Plant Nutrition, University of New England, New England

Buhaira, Soverda, N, Lestari, PA, \& Achnopa, Y, 2013, Pertumbuhan Dan Hasil Tanaman Kedelai Dengan Pemberian Mikokompos Dalam Kondisi Cekaman Air, Jurnal Agronomi, vol.13, no.2, hal. 33-42

Campbell, NA, Reece, JB, \& Mitchell, LG, 2003, Biologi, Jilid 2, Edisi Kelima, Alih Bahasa, Wasmen, Penerbit Erlangga, Jakarta

Cahyani, RV, 2009, Pengaruh Beberapa Metode Sterilisasi Tanah Terhadap Status Hara, Populasi Mikrobiota, Potensi Infeksi Mikoriza, dan Pertumbuhan Tanaman, Jurnal Ilmiah Ilmu Tanah Dan Agroklimatologi, vol. 6, no.1, hal 43-52 
Fikrinda, Zuraida, Yusnizar, Marlina, 2011, Serapan hara $\mathrm{N}, \mathrm{P}$, dan $\mathrm{K}$ pada tanaman jagung dan status hara $\mathrm{N}, \mathrm{P}$, dan $\mathrm{K}$ pada tanah yang diinokulasi fungi mikoriza arbuskula dan diberi pupuk kandang sebagai upaya reklamasi lahan terkena tsunami. Di dalam: Budi SW, Turjaman M, Mardatin NF, Nusantara AD, Trisilawati O, Sitepu IR, Wulandari AS, Riniarti M, Setyaningsih L, editor. Percepatan Sosialisasi Teknologi Mikoriza untuk Mendukung Revitalisasi Pertanian, Perkebunan, dan Kehutanan. Prosiding Seminar Nasional Mikoriza II; 2007 Jul 17-21; Bogor, Indonesia. Bogor (ID): Seameo Biotrop. hal 65-71

Gaspers, V, 1991, Metode Perancangan Percobaan, CV.ARMICO, Bandung

Hadianur, Syafrudin, Kesumawati, E, 2016, Pengaruh Jenis Fungi Mikoriza Arbuscular terhadap Pertumbuhan dan Hasil Tanaman Tomat (Lycopersicum esculentum Mill), Jurnal Agrista, vol. 20, no. 3, hal. 126 - 134

Iliana, Y, 2017, Pengaruh Aplikasi Kombinasi Pupuk Kandang Ayam dan Pupuk KCl Terhadap Pertumbuhan dan Hasil Produksi Jagung Manis (Zea mays Saccharata Sturt.), Skripsi, Fakultas Pertanianan, Universitas Lampung, Bandar Lampung

Ishak, YS, Bahua, M, Limonu \& Marleni, 2013, 'Pengaruh Pupuk Organik Kotoran Ayam terhadap Pertumbuhan Tanaman Jagung (Zea mays L.) di Dulomo Utara Kota Gorontalo. Gorontalo', Jurnal Agroteknotropika, vol.1, no.2, hal. 210-218

Lakitan, B, 1995, Fisiologi Tumbuhan, PT. Raja Grafindo Persada, Jakarta

Lakitan, B, 2000, Dasar-dasar Fisiologi Tumbuhan, PT. Raja Grafindo Persada, Jakarta

Lana, Wayan, 2009, Pengaruh Dosis Pupuk Kandang Sapi dan Mikoriza Terhadap Pertumbuhan dan Hasil Tanaman Kacang Tanah (Arachis hypogaea L.) di Lahan Kering, Majalah Ilmiah Universitas Tabanan, vol. 6, no.1, hal. 49-55

Leskona D, Riza, L, \& Mukarlina, 2013, 'Pertumbuhan Jagung (Zea mays L). dengan Pemberian Glomus aggregatum dan Biofertilizer Pada Tanah Bekas Penambangan Emas', Jurnal Protobiont, vol. 2, no. 3, hal. 176-180

Lingga, P, 2010, Petunjuk Penggunaan Pupuk, Penebar Swadaya, Jakarta

Malik, M, Kuswanta FH, Sri, Y \& Maria, VR, 2016, 'Pengaruh Aplikasi Fungi Mikoriza Arbuskula dan Pupuk Kandang dengan Berbagai Dosis terhadap Pertumbuhan dan Produksi Kedelai (Glycine max L. Mer.) Pada Ultisol', Jurnal Agrotek Tropika, vol. 5, no. 2, hal. 63-67
Mayadewi, NNA, 2007, 'Pengaruh Jenis Pupuk Kandang Dan Jarak Tanam Terhadap Pertum-buhan Gulma dan Hasil Jagung Manis', Jurnal Agritrop, vol. 4, no. 26, hal. 153-159

Marlina, N, Aminah, RIS, Rosmiah, \& Setel, LR, 2015, 'Aplikasi Pupuk Kandang Kotoran Ayam pada Tanaman Kacang Tanah (Arachis hypogeae L.)', Jurnal Biosaintifika, vol. 7, no. 2, hal. 137-141

Merdekawati, A, Riza, L, \& Mukarlina, 2014, Pertumbuhan Cabai (Capsicum annuum L.) dengan pemberian Gigaspora margarita dan Bokashi Jerami Padi Pada Tanah Gambut, Jurnal Protobiont, vol. 3, no. 3, hal. 63-68

Musfal, 2010, Potensi Cendawan Mikoriza Arbuskula Untuk Meningkatkan Hasil Tanaman Jagung, Jurnal Litbang Pertanian, vol. 29, no. 4, hal. 154-158

Norland, M, 1993, Soil Factor Affecting Mychorrizal use in Surface Mine Reclamation, Bureau of Mines Information Circular, United States Department on The Interior

Novizan, 2002, Petunjuk Pemupukan yang Efektif, PT. Agro Media Pustaka, Depok

Prasasti, OH, KI Purwani, S Nurhatika, 2013. Pengaruh mikoriza Glomus fasciculatum terhadap pertumbuhan vegetatif tanaman Kacang Tanah yang terinfeksi patogen Sclerotium rolfsii. Jurnal Sains dan Seni Pomits, vol. 2, no. 2, hal $74-78$

Salisbury, JW \& Ross, 1995, Fisiologi Tumbuhan Jilid 2, Institut Teknologi Bandung, Bandung

Sastrahidayat, 2011, Rekayasa Pupuk Hayati Mikoriza dalam Meningkatkan Produksi Pertanian, Universitas Brawijaya Press, Malang

Saukani, A, 2015, Pengaruh Pemberian Pupuk Kandang dan Kapur Dolomit Terhadap Pertumbuhan dan Hasil Tanaman Kubis Bunga (Brassica oleracea var botrytis L.) Pada Tanah Gambut Pedalaman, Skripsi, Universitas Muhammadiyah Palangkaraya, Fakultas Pertanian dan Kehutanan, Program Studi Agroteknologi

Sidabutar, RM, 2006, Pengaruh Pemberian Pupuk Organik Terhadap Produksi Sawi (Brassica juncea L.) dan Beberapa Sifat Kimia Tanah Andisol, Departemen Ilmu Tanah, USU Repository, Medan

Suherman, Rahim, I, Akib, A, 2012, Aplikasi Mikoriza Vesikular Arbuskular Terhadap Pertumbuhan Dan Produksi Tanaman Kedelai (Glycine max L. Merrill), Jurnal Galung Tropika, vol.1, no.1, hal. 1-6 
Suprapto, \& Pasaribu, D. 1985. Kedelai. Pusat Penelitian Pengambangan Bogor. Bogor

Suryati, D, Susanti, N, \& Hasanudin, 2009, Waktu Aplikasi Pupuk Nitrogen untuk Pertumbuhan dan Hasil Kedelai Varietas Kipas Putih Dan Galur 13 ED, Jurnal Akta Agrosia, vol. 12, no. 2, hal. 204-212
Tufaila, M, 2013, Aplikasi Kompos Kotoran Ayam untuk Meningkatkan Hasil Tanaman Mentimun (Cucumis sativus L.) di Tanah Masam, Jurnal Agroteknos, vol. 4, no. 2, hal. 119-126

Yusnaini, S, 2009, 'Pengaruh Pemberian Cendawan Mikoriza Arbuskula (CMA) dan Dosis Pupuk Kandang Ayam terhadap Pertumbuhan Dan Produksi Jagung (Zea mays L.)', Buletin Agrohortikultura, vol. 3, no. 3, hal. 323-329 